\title{
Differential activation of human T cells to allogeneic endothelial cells, epithelial cells and fibroblasts in vitro
}

\author{
Dmitry Samsonov ${ }^{1,2}$, Christopher Geehan ${ }^{1,2}$, Craig B Woda ${ }^{1,2}$ and David M Briscoe ${ }^{3 *}$
}

\begin{abstract}
Background: In the direct pathway, T cells recognize intact donor major histocompatability complexes and allogeneic peptide on the surface of donor antigen presenting cells (APCs). Indirect allorecognition results from the recognition of processed alloantigen by self MHC complexes on self APCs. In this study, we wished to evaluate the relative contribution of different intragraft cells to the alloactivation of naïve and memory $T$ cells though the direct and the indirect pathway of allorecognition.

Methods: The processing of membrane fragments from IFNY-treated single donor endothelial cells (EC), fibroblasts or renal epithelial cells (RPTEC) was evaluated by DiOC labeling of each cell type and flow cytometry following interaction with PBMC. Direct pathway activation of naïve CD45RA ${ }^{+}$or memory CD45RO ${ }^{+} \mathrm{CD}^{+} \mathrm{T}$ cells was evaluated following coculture with IFNY-treated and MHC class II-expressing EC, fibroblasts or RPTEC. Indirect pathway activation was assessed using $\mathrm{CD}_{4} 5 \mathrm{RA}^{+}$or $\mathrm{CD} 45 \mathrm{RO}^{+} \mathrm{CD}^{+} \mathrm{T}$ cells cocultured with autologous irradiated APCs in the absence or presence of sonicates derived from IFNy-treated allogeneic EC, fibroblasts or RPTEC. Activation of T cells was assessed by $\left[^{3} \mathrm{H}\right]$ thymidine incorporation and by ELISpot assays.

Results: We find that CD14 ${ }^{+}$APCs readily acquire membrane fragments from fibroblasts and RPTEC, but fail to acquire membrane fragments from intact EC. However, APCs process membranes from EC undergoing apoptosis. There was a notable direct pathway alloproliferative response of $C D 45 \mathrm{RO}^{+} \mathrm{CD} 4^{+} \mathrm{T}$ cells to IFNy-treated EC, but not to fibroblasts or RPTEC. Also, there was a minimal direct pathway response of CD45RA ${ }^{+} \mathrm{CD} 4^{+} \mathrm{T}$ cells to all cell types. In contrast, we found that both $\mathrm{CD} 45 \mathrm{RA}^{+}$and $\mathrm{CD} 45 \mathrm{RO}^{+} \mathrm{CD}^{+} \mathrm{T}$ cells proliferated following coculture with autologous APCs in the presence of sonicates derived from IFNy-treated EC, fibroblasts or RPTEC. By ELISpot, we found that these T cells stimulated via the indirect pathway also produced the cytokines IFNy, IL-2, IL-4 and IL-5.

Conclusions: Recipient APCs may readily process membrane fragments from allogeneic intragraft cells, but not from EC unless they are undergoing apoptosis. This processing is sufficient for indirect pathway alloactivation of both $\mathrm{CD}_{4} \mathrm{RA}^{+}$and $\mathrm{CD} 4 \mathrm{RO}^{+} \mathrm{CD}^{+} \mathrm{T}$ cells. Only graft vascular EC mediate direct pathway reactivation of $\mathrm{CD}^{+} \mathrm{T}$ cells.
\end{abstract}

Keywords: Allorecognition, monocytes, APC, Endothelial cells, Fibroblasts, Tubular epithelial cells, T cells

\footnotetext{
* Correspondence: david.briscoe@childrens.harvard.edu

${ }^{3}$ Division of Nephrology, Children's Hospital Boston, 300 Longwood Ave, Boston, MA 02115, USA

Full list of author information is available at the end of the article
} 


\section{Background}

Recipient $\mathrm{CD}^{+}{ }^{+} \mathrm{T}$ cell recognition of alloantigen is the central and primary event that ultimately leads to the initiation of allograft rejection [1-3]. It is now well established that alloactivation of $\mathrm{T}$ cells occurs via two distinct pathways [4-10]. In the direct pathway of allorecognition, $\mathrm{CD}^{+} \mathrm{T}$ cells recognize intact allogeneic major histocompatibility complex (MHC) antigens expressed on the surface of donor cells. In the indirect pathway of allorecognition, $\mathrm{CD}^{+} \mathrm{T}$ cells recognize allogeneic peptides processed and presented by self-MHC molecules on the surface of recipient antigen presenting cells (APCs). While the central determinant of alloresponsiveness is recognition of alloantigen, it has become evident that both pathways can contribute to the development of acute and chronic rejection and/or ongoing injury to the graft $[7,11,12]$.

In traditional immunological models, it is suggested that both naive and memory $\mathrm{CD} 4^{+} \mathrm{T}$ cells contribute to rejection through the direct pathway, whereas indirect pathway allorecognition is dominantly associated with activation of the naive repertoire of T cells $[7,10,13,14]$. This model is based on the hypothesis that the memory $\mathrm{T}$ cell repertoire results from expanded populations of $\mathrm{T}$ cells that have responded to previous antigen encounters. In contrast, activation of naïve populations of $\mathrm{T}$ cells is continuous and results from ongoing APC-dependent presentation of alloantigen via both direct and indirect pathways [13]. Since, naïve T cells are largely made up of single cells with different specificities, this indicates that the allogeneic response(s) can be very diverse. In addition, it is well known that the precursor frequency of $\mathrm{T}$ cells with direct allospecificity is high $[4,15]$. This suggests that the memory subset alone is unlikely to account for the direct allorecognition response. While the frequency of $\mathrm{T}$ cells with indirect specificity is low, they are well established to increase over time following transplantation [16-18]. Thus, it is likely that the continuous activation of naïve $\mathrm{T}$ cells via indirect presentation of alloantigen by self-APCs will be dominant for the generation of persistent allogeneic responses.

The vascular endothelium functions in the recruitment of recipient immune competent cells into the graft [1921]. Donor graft vascular endothelial cells (EC) also express MHC class I and II molecules, and have been reported to be potent to provide costimulation for the effective alloactivation of human $\mathrm{T}$ cells [20,22-24]. In addition, following re-endothelialization of donor grafts, recipient EC lining vessels within the graft have been found to be efficient in the activation of T cells in a selfrestricted manner via the indirect pathway of alloactivation $[25,26]$. Since both acute and chronic rejection requires interactions among $\mathrm{T}$ cells and graft vascular
EC, it is proposed that this cell type may serve as a primary candidate to foster the reactivation of $\mathrm{T}$ cells, and perhaps the modification of activation responses via both direct and indirect allorecognition [8,25-27]. However, some reports have suggested that endothelial cells lack the ability to provide effective costimulation to $\mathrm{T}$ cells $[28,29]$, and others suggest that the expression of MHC class II expression by endothelial cells is not necessary for the rejection response [30]. Nevertheless, these observations do not exclude the importance of donor EC in the promotion of indirect allorecognition via interactions with APCs [23], and their effect in this latter response is poorly understood.

Few studies have evaluated the ability of interstitial intragraft cells to facilitate direct and indirect allorecognition. The lack of expression of costimulatory molecules by fibroblasts and renal tubular epithelial cells (RPTEC) limits their ability to induce $\mathrm{T}$ cell activation [31-34]. In this report, we used well-established in vitro models to compare the effect of EC, fibroblasts and RPTEC in direct and indirect alloactivation of naïve

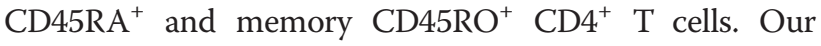
findings indicate that EC, but not fibroblasts or RPTEC, provide direct pathway allorecognition to $\mathrm{CD}_{4} \mathrm{RO}^{+}$ memory subsets of $\mathrm{CD}^{+}{ }^{+} \mathrm{T}$ cells. In addition, we find that all cell types facilitate indirect allorecognition to both $\mathrm{CD}_{45 \mathrm{RA}^{+}}$naïve and $\mathrm{CD}_{45 \mathrm{RO}^{+}}$memory $\mathrm{CD}^{+} \mathrm{T}$ cell subsets.

\section{Methods}

\section{Cell Isolation and Culture}

Single donor endothelial cells (EC) were isolated from human umbilical cords as previously described [35], and were grown in M199 medium (Bio Whittaker) containing $20 \%$ FCS (GIBCO BRL, Grand Island NY) or 10\% human serum, EC growth supplement, 1\% penicillin/streptomycin, l-glutamine, and heparin. Single donor fibroblasts and renal tubular epithelial cells (RPTEC) were purchased from Clonetics and cultured in CC-4126 FGM 2 or CC-4127 REGM (Clonetics, Walkersville MD) according to the manufacturer's protocol. EC, fibroblasts and RPTEC were treated with IFNY $(1000 \mathrm{U} / \mathrm{ml}, \mathrm{R} \& \mathrm{D}$ Systems, Minneapolis, $\mathrm{MN}$ ) for $72 \mathrm{~h}$ prior to use. EC were used in subculture 3-4. Apoptosis was induced in EC monolayers following treatment with TNF- $\alpha(200 \mathrm{U} / \mathrm{ml}$, Biogen, Cambridge MA) and cyclohexamide (2 ng/ml, Sigma, St. Louis, MO) for 7 h. Peripheral blood mononuclear cells (PBMC) were isolated by Ficoll-Hypaque gradient centrifugation from healthy volunteers. $\mathrm{CD}^{+} \mathrm{T}$ cells were isolated from PBMC by positive selection using anti-CD4-coated magnetic beads (Invitrogen, Grand Island NY) according to the manufacturer's protocol. $\mathrm{CD}_{4}^{+} \mathrm{CD} 45 \mathrm{RA}^{+}$and $\mathrm{CD}_{4}^{+}$ $\mathrm{CD}_{45 \mathrm{RO}^{+}}$cells were isolated from $\mathrm{CD} 4^{+}$cells by negative selection using magnetic beads coated with mouse anti- 
human CD45RO and CD45RA antibodies (Invitrogen, Grand Island NY).

\section{Lymphocyte transmigration assays}

Transmigration experiments were conducted using EC, fibroblasts or RPTEC monolayers cultured on fibronectin $(50 \mu \mathrm{g} / \mathrm{ml})$ coated $3 \mu \mathrm{m}$ pore size transwell inserts (Costar, Cambridge, MA, USA) as previously described [35,36]. A total of $3 \times 10^{3} \mathrm{EC}$, fibroblasts or RPTEC were seeded onto inserts and were allowed to grow for 4-5 days. Monolayers were treated with IFN $\gamma(1000 \mathrm{U} / \mathrm{ml}, \mathrm{R} \& \mathrm{D}$ systems) for the last 72 culture. Confluence of the monolayers was confirmed by Coomasie staining using standard techniques [37]. Monolayers were labeled with DiOC-16 $(5 \mu \mathrm{g} / \mathrm{ml}$, Molecular Probes, Eugene OR, USA), which incorporates into the membranes of cells and has an emission at $501 \mathrm{~nm}$. A total of $1 \times 10^{6}$ PBMC were placed into the upper transwell and cells were collected from the bottom well after $1.5 \mathrm{~h}$. Following collection, DiOC uptake was analyzed on $\mathrm{CD} 14^{+} \mathrm{CD} 4^{+}$and $\mathrm{CD} 8^{+}$cells by flow cytometry.

\section{Flow cytometry}

Confluent monolayers were harvested in Trypsin/EDTA (Sigma, St. Louis, MO) and were analyzed by indirect immunofluorescence staining and flow cytometry as previously described [23]. Briefly, cells were incubated in optimal concentrations of the primary antibodies anti-HLA DR (LB3.1, ATCC, Manassas, VA), negative control mouse IgG (K16/16, a gift from Michael Gimbrone, Brigham and Women's Hospital) or positive control antiICAM-1 (RR1/1, a gift from TS Springer) for 30 mins on ice. Cells were washed and subsequently incubated in FITC-conjugated anti-mouse secondary antibody (Jackson, Immunoresearch, West Grove, PA) for an additional 30 mins on ice, and stained cells were washed and fixed in $1 \%$ paraformaldehyde prior to analysis. Leukocytes were stained using Phycoerythrin (PE) conjugated antihuman -CD14,-CD4 and -CD8 antibodies (PharMingen, San Diego CA) or isotype negative controls using standard techniques. All stained cells were analyzed using a FACSCalibur cell sorter (Becton Dickinson, Mountain View, CA) and CellQuest and Flowjo software.

\section{PBMC-allogeneic cell coculture}

EC, fibroblasts or RPTEC were cultured to confluence in fibronectin-coated 24-well flat-bottom plates (Costar) coated with fibronectin $(50 \mu \mathrm{g} / \mathrm{ml})$ and treated with IFNy $(1000 \mathrm{U} / \mathrm{ml})$ for $72 \mathrm{~h}$. PBMC $\left(1 \times 10^{6} /\right.$ well $)$ were added and were cultured for 7 days in standard RPMI 1640 medium containing $10 \%$ autologous serum. Subsequently, PBMC were harvested by washing with HBSS and $\mathrm{CD} 4^{+} \mathrm{T}$ cells were isolated by positive selection (Invitrogen, Grand Island NY) and were rested in culture medium containing 2.5\% of human T-stim without PHA (Becton Dickinson
Labware, Bedford, MA) for 5 days. The allogeneic HLA mismatch between PBMCs and stimulator EC, fibroblasts or RPTEC was unknown, but was presumed based on consistency of the response in multiple repeated experiments.

\section{Preparation of Sonicates}

Cell membranes were prepared as sonicates from IFN- $\gamma$ treated EC, fibroblasts and RPTEC. Exactly $8 \times 10^{6}$ of each cell type was washed and suspended in $1 \mathrm{ml}$ of sterile PBS and was sonicated using a tip sonicator (Branson Sonifer 250) fitted with a $2 \mathrm{~mm}$ probe. Disrupted cells were centrifuged for $10 \mathrm{~min}$ at $500 \mathrm{~g}$ to remove debris. A total of $20 \mu \mathrm{l}$ of sonicate was used in each assay. As a quality control, the protein content per $\mathrm{ml}$ was measured in occasional sonicate supernatants by standard Bradford assay. Sonicates were frozen at $-20^{\circ} \mathrm{C}$ and thawed at $37^{\circ} \mathrm{C}$ before use.

\section{Indirect allorecognition assays}

$\mathrm{CD}^{+} \mathrm{T}$ cells $\left(1 \times 10^{5} /\right.$ well $)$ isolated from primary cultures (above) were used with autologous APCs in proliferation assays. Autologous APCs (1 $1 \times 10^{5} /$ well $)$ were isolated from T cell-depleted PBMC, were irradiated (1750 rad) and used as stimulators. Assays were performed in round-bottom 96-well plates (Costar). Sonicates from the allogeneic cells, were added (as above) to each culture and, after 6 days proliferation was assessed by standard $\left[{ }^{3} \mathrm{H}\right]$ thymidine incorporation assays $(1 \mu \mathrm{Ci} /$ well $)$ for the last $16 \mathrm{~h}$ of the coculture.

\section{ELISPOT assays}

ELISpot was performed in 96-well plates (Cellular Technology Ltd., Cleveland, $\mathrm{OH}$ ) coated overnight with capture cytokine antibodies diluted in sterile PBS. Antibodies were mouse anti-human IFNY (clone 2 G1, Endogen, Wolburn, MA, $4 \mu \mathrm{g} / \mathrm{ml}$ ), mouse anti-human IL-2 (clone 5355, R\&D Systems Inc., Minneapolis, MN, $5 \mu \mathrm{g} / \mathrm{ml}$ ), mouse anti-human IL-4 (clone 8D4-8, BD PharMingen, San Diego, CA, $5 \mu \mathrm{g} / \mathrm{ml}$ ) or rat anti-human IL-5 (clone TRFK5, PharMingen, San Diego, CA, $5 \mu \mathrm{g} / \mathrm{ml}$ ). After blocking for $1 \mathrm{~h}$ with PBS/1\%BSA, the plates were washed and $\mathrm{CD}^{+} \mathrm{T}$ cells $\left(2 \times 10^{5} /\right.$ well $)$ were cultured with autologous APCs $\left(2 \times 10^{5} /\right.$ well $)$ in the absence or presence of sonicate. The plates were incubated at $37^{\circ} \mathrm{C}$ in $5 \% \mathrm{CO}_{2}$ for 24-36 h. Detection antibodies were biotinylated mouse anti-human IFN- $\gamma$ (clone B133.5, Endogen, $2 \mu \mathrm{g} / \mathrm{ml}$ ), mouse anti-human IL-2 (clone 5334, R\&D Systems Inc., $50 \mathrm{ng} / \mathrm{ml}$ ), rat anti-human IL-4 (clone MP4-25D2, BD PharMingen, $2 \mu \mathrm{g} / \mathrm{ml}$ ) and rat anti-human IL-5 (clone JES1-5A10, PharMingen, $2 \mu \mathrm{g} / \mathrm{ml}$ ). After overnight incubation at $4^{\circ} \mathrm{C}$, the plates were washed and cytokines were detected using streptavidin HRP (Daco, Carpenteria, CA) and 3-amino-9- 
ethyl carbazole (Pierce Chemical Co., Rockford, IL). Spots were counted using a computer-assisted ELISpot image analyzer (Cellular Technologies Limited).

\section{Statistical analyses}

Statistical analysis was performed using the student $t$ test for two groups of data and by one-way ANOVA for three or more groups. $P$ values $<0.05$ were considered statistically significant.

\section{Results}

$\mathrm{CD} 14^{+}$monocytes acquire membrane fragments from fibroblasts and RPTEC, but not EC

We initially evaluated whether APCs acquire membrane fragments from allogeneic cells during brief interactions in the course of transmigration. We used a standard transwell model in which PBMC were allowed to transmigrate through confluent IFN $\gamma$-treated EC, fibroblasts or RPTEC. Prior to the assay, cells were labeled with lipophylic DiOC16 , which is well established to stably incorporate into cell

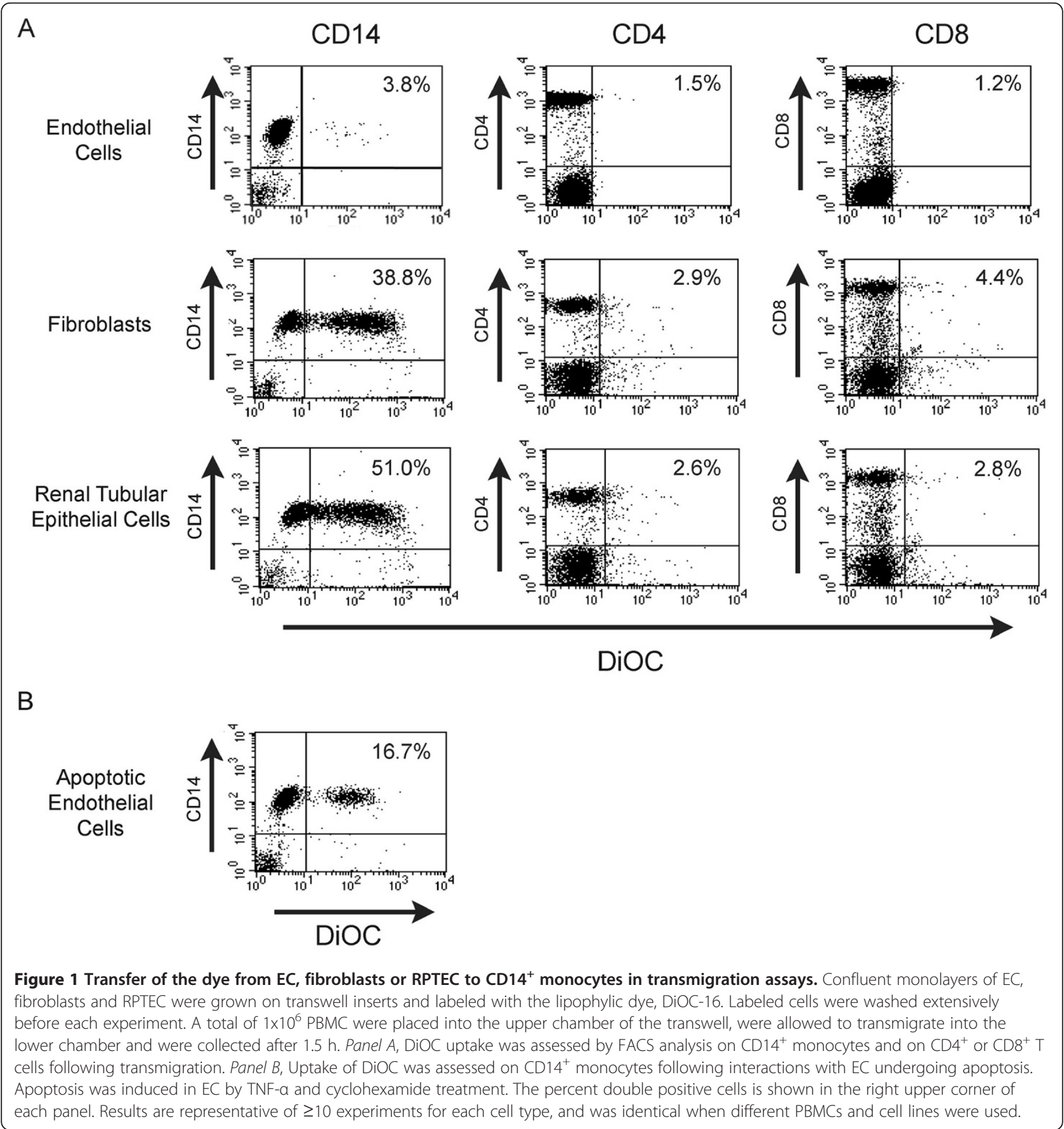


membranes. As illustrated in Figure 1, we found that 35$65 \%$ of $\mathrm{CD}_{14}{ }^{+}$monocytes acquired dye after interaction with both fibroblasts and RPTEC. However, surprisingly, the transfer of dye was very limited after interaction with EC. We also found that neither $\mathrm{CD} 4^{+} \mathrm{T}$ cells nor $\mathrm{CD} 8^{+} \mathrm{T}$ cells acquire dye from any allogeneic cell type indicating that the transfer was related to phagocytosis of membrane rather than through cell surface membrane transfer (as can occur in the semi-direct pathway of allorecognition $[7,38]$ ). To further confirm that intact EC fail to transfer membrane to APCs, we also assessed transfer when PBMC transmigrated across EC undergoing apoptosis (TNF $\alpha$ - and cyclohexamide- treated cells). As illustrated in Figure 1B, we find that APCs acquire DiOC-labeled membrane from apoptotic EC (15-25\% cells) as compared to untreated or IFN $\gamma$-treated EC (3-10\% cells). In contrast, the transmigration of PBMC across apoptotic fibroblasts or RPTEC did not alter DiOC-labeled membrane uptake from that described above (data not shown). Therefore, it is possible that acute injury or alloimmune targeting of EC may be a factor in the initiation of indirect processing of alloantigen by APCs. This process may result in crosstalk between both pathways of allorecognition, as described [8].

\section{Direct and indirect allorecognition by $\mathrm{CD}^{2} 5 \mathrm{RA}^{+}$and $\mathrm{CD}^{2} 5 \mathrm{RO}^{+} \mathrm{CD}^{+} \mathrm{T}$ cells in response to IFN $\gamma_{\text {-treated }} \mathrm{EC}$, fibroblasts or RPTEC}

We next wished to compare the ability of EC, fibroblasts and RPTEC to induce direct and indirect pathway alloactivation of naive $\mathrm{CD} 45 \mathrm{RA}^{+}$and memory $\mathrm{CD} 45 \mathrm{RO}^{+} \mathrm{CD} 4^{+} \mathrm{T}$ cells. CD45RA ${ }^{+}$and $C D 45 \mathrm{RO}^{+}$cells were isolated by negative selection from pure populations of $\mathrm{CD}_{4}^{+} \mathrm{T}$ cells ( $>90 \%$ purity by FACS, data not shown) and were cocultured with IFN $\gamma$-treated EC, fibroblasts or RPTEC for 5 days. As illustrated in Figure 2A, and consistent with other reports $[23,39,40]$, we find that our IFN $\gamma$-treated EC, fibroblasts and RPTEC express high levels of MHC class II. However, CD45RO ${ }^{+} \mathrm{CD}^{+} \mathrm{T}$ cells showed significant proliferation only in response to culture with allogeneic EC, and had minimal proliferative responses when cultured with fibroblasts or RPTEC (Figure 2B). In contrast, there was a minimal proliferative response of CD45RA ${ }^{+} \mathrm{CD} 4^{+} \mathrm{T}$ cells to all allogeneic stimulator cell types (Figure 2B). This observation is consistent with previously published reports indicating that EC function in the activation of allogeneic $\mathrm{T}$ cells [22,23,41,42]. They are also consistent with previous studies indicating that EC fail to provide sufficient costimulation for the initiation of naive $\mathrm{T}$ cell activation responses [23,28].

In order to evaluate the effect of each cell type in indirect alloactivation, we next cocultured $\mathrm{CD}_{4} 5 \mathrm{RA}^{+}$or

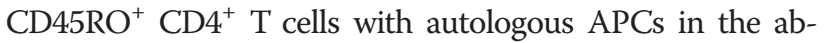
sence or presence of sonicate derived from allogeneic $72 \mathrm{~h}$ IFN $\gamma$-treated EC, fibroblasts and RPTEC (as shown in
Figure 2A). In these assays, $\mathrm{T}$ cells cultured in the presence of autologous APCs without sonicate served as a negative control. Illustrated in Figure 3A, we find that both naive $\mathrm{CD}_{45 \mathrm{RA}^{+}}$as well as memory $\mathrm{CD} 45 \mathrm{RO}^{+} \mathrm{CD}^{+}{ }^{+} \mathrm{T}$ cells proliferate to sonicates prepared from all cell types. As a control, each $\mathrm{T}$ cell subset failed to proliferate to sonicate alone in the absence of autologous APCs (Figure 3B). These observations indicate that indirect allorecognition is a most potent mechanism for the allogeneic activation of both naïve and memory $\mathrm{T}$ cells.

\section{Effect of sensitization on indirect allorecognition by $\mathrm{CD} 4^{+}$ $T$ cells}

We next created an in vitro model to evaluate whether there is a difference in indirect responses among unsensitized and sensitized $\mathrm{CD} 4^{+} \mathrm{T}$ cells. For this purpose, we cultured PBMC with IFN $\gamma$-treated EC, fibroblasts or RPTEC. After 7 days, the $\mathrm{CD} 4^{+} \mathrm{T}$ cells were isolated from the cultures and were rested in culture medium alone. After 5 days of rest, these sensitized T cells (or freshly isolated unsensitized cells) were then used as responders in cocultures with autologous APCs in the absence or presence of sonicates derived from the allogeneic EC, fibroblast or RPTEC used in the primary culture. Proliferation was again assessed on day 6. Illustrated in Figure 4, we found no difference in the proliferative responses of unsensitized or sensitized $\mathrm{T}$ cells in these indirect allorecognition assays. By ELISpot (48 h), we found variations in individual cytokine production between sensitized and unsensitized cells (Figure 4B). However, the overall production of cytokines was at high levels reflective of the activation status of the $\mathrm{T}$ cells and there were no significant differences between responses in unsensitized and sensitized cells (data not shown). ELISpot counts for IFNY were generally higher when EC were used as the alloantigen, as compared to assays where fibroblasts and RPTEC were used (Figure 4B). Collectively, these observations further confirm that the indirect response is potent to initiate $\mathrm{T}$ cell activation, and indicate that $\mathrm{T}$ cells primed through the indirect pathway may be reactivated within allografts upon encounter with self-APCs.

\section{Discussion}

In the current study, we find that MHC class II-expressing EC are potent for direct pathway allogeneic reactivation of memory $\mathrm{T}$ cell subsets, and that direct pathway activation does not occur following interactions with fibroblasts or renal tubular epithelial cells. In addition, we find that $\mathrm{CD}_{1}{ }^{+}$monocyte/APCs readily acquire membrane particles from fibroblasts as well as renal epithelial cells and that this process is sufficient to induce indirect pathway allogeneic activation of both naïve and memory T cells. In contrast, the ability of monocytes to phagocytose membrane particles from intact EC is limited, and acquisition 


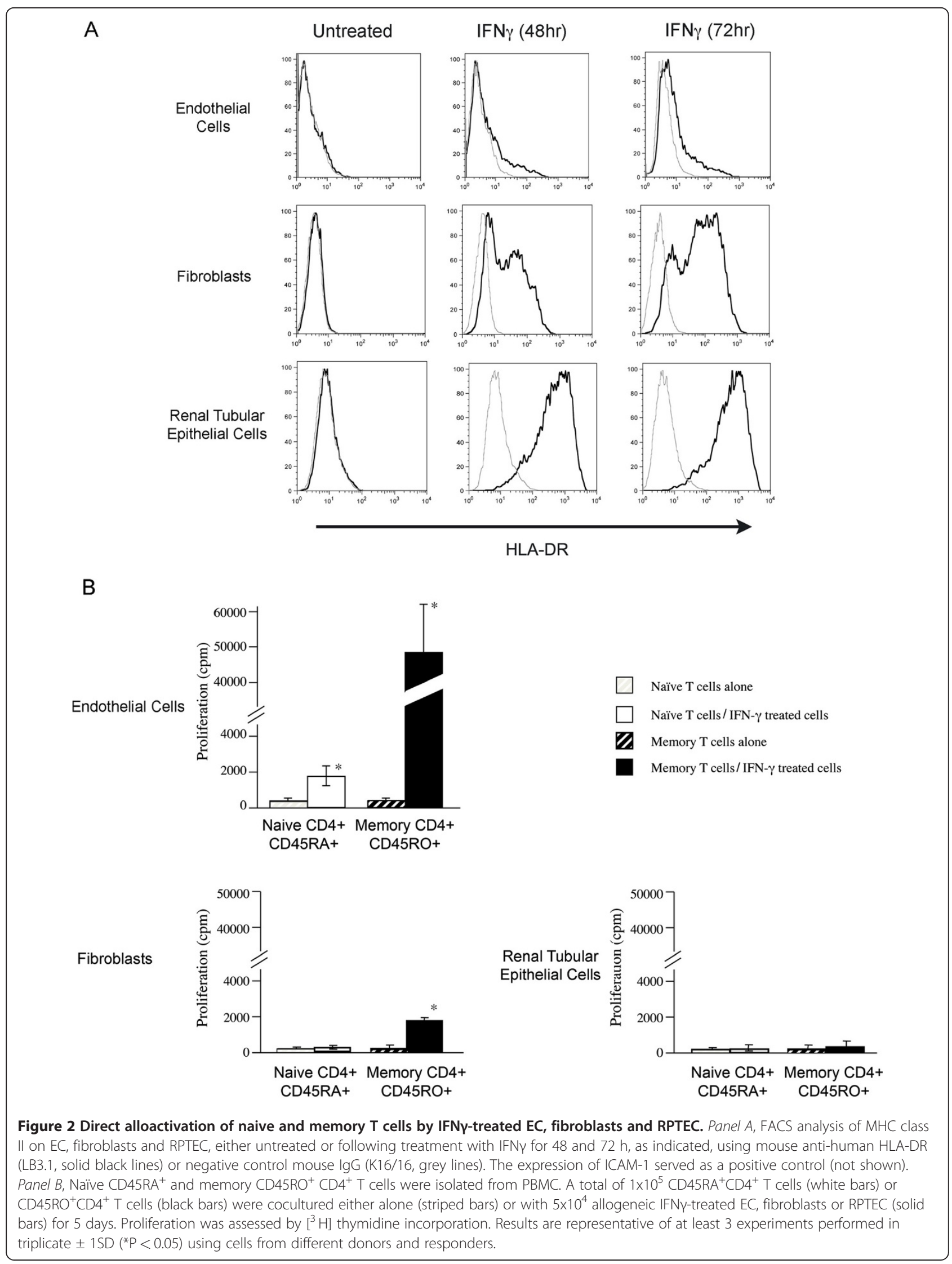


A
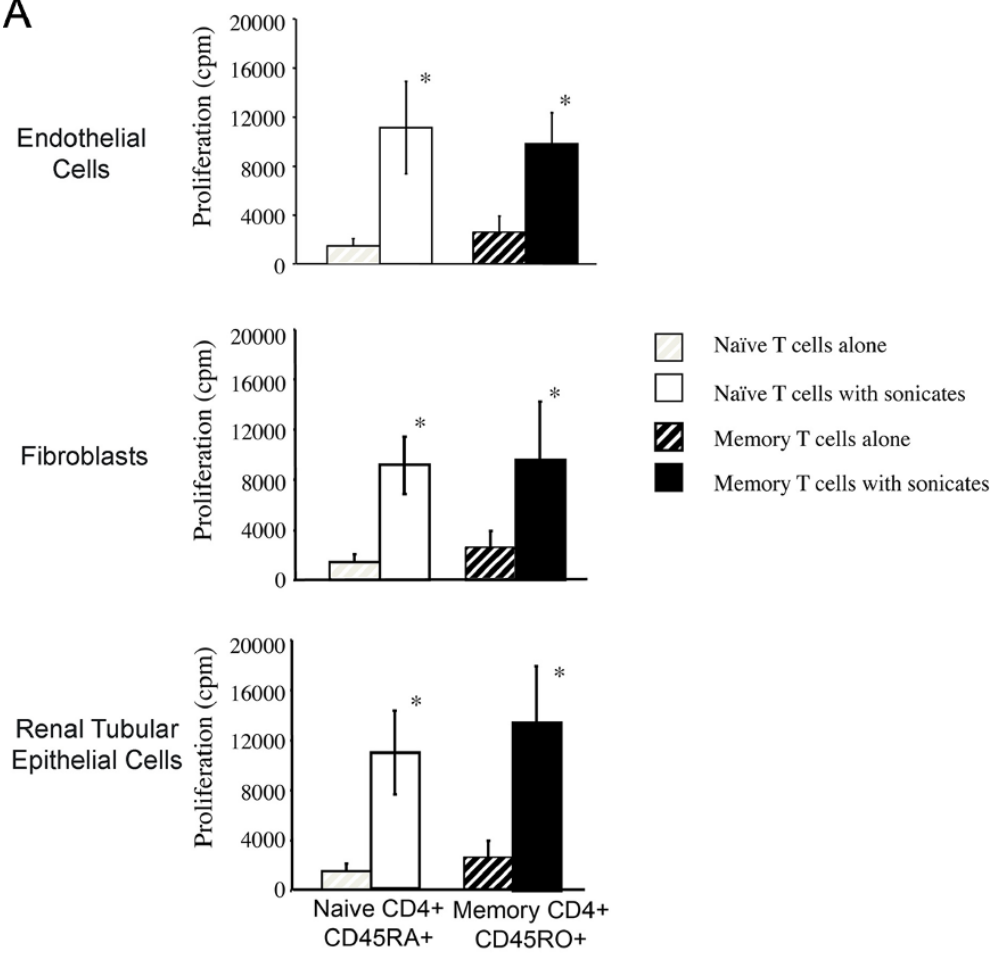

B

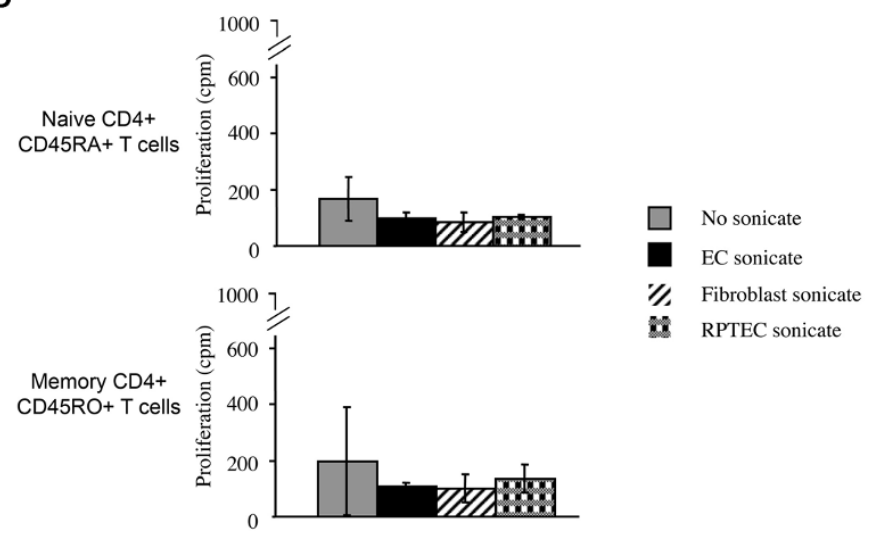

Figure 3 Indirect alloactivation of naive and memory T cells following coculture with autologous APCs in the presence of sonicates derived from allogeneic EC, fibroblasts or RPTEC. Naiive CD45RA ${ }^{+}$cells and memory CD45RO ${ }^{+} C D 4^{+} T$ cells were isolated from PBMC as described in Methods. Panel $A, 1 \times 10^{5} \mathrm{CD}_{5} \mathrm{RA}^{+} \mathrm{CD} 4^{+} \mathrm{T}$ cells (white bars) or $\mathrm{CD} 45 \mathrm{RO} \mathrm{C}^{+} \mathrm{CD} 4^{+} \mathrm{T}$ cells (black bars) were cocultured for 6 days with $1 \times 10^{5}$ irradiated autologous PBMC either alone (striped bars) or in the presence of sonicate (solid bars) prepared from allogeneic IFNy treated EC, fibroblasts or RPTEC. Proliferation was assessed by $\left[{ }^{3} \mathrm{H}\right]$ thymidine incorporation. Results are representative of 3 different experiments performed in triplicate $\pm 1 S D\left({ }^{*} P<0.05\right)$. Panel B, $1 \times 10^{5} \mathrm{CD}_{5}$ RA $A^{+}$(Upper Panel) or CD45RO ${ }^{+}$(Lower Panel) CD4 ${ }^{+} \mathrm{T}$ cells were cultured for 6 days either alone (gray bars) or with sonicate prepared from allogeneic IFNy-treated EC (black bars), fibroblasts (striped bars) or RPTEC (checked bars). Proliferation was assessed by $\left[{ }^{3} \mathrm{H}\right]$ thymidine incorporation. The illustrated results in Panels $A$ and $B$ are representative of 3 different experiments performed in triplicate \pm 1SD.

by APCs requires apoptosis of EC. Nevertheless, once APCs process particulates from allogeneic EC, these APCs are most potent to induce indirect alloactivation of $\mathrm{T}$ cell subsets. These observations are consistent with the hypothesis that memory $\mathrm{CD} 4^{+} \mathrm{T}$ cells contribute to rejection through direct pathway interactions with allogeneic EC. In addition, they indicate that indirect pathway allorecognition can occur following processing of alloantigen by all cell types, and this pathway is dominant for the activation of naïve repertoires of human $\mathrm{T}$ cells. 


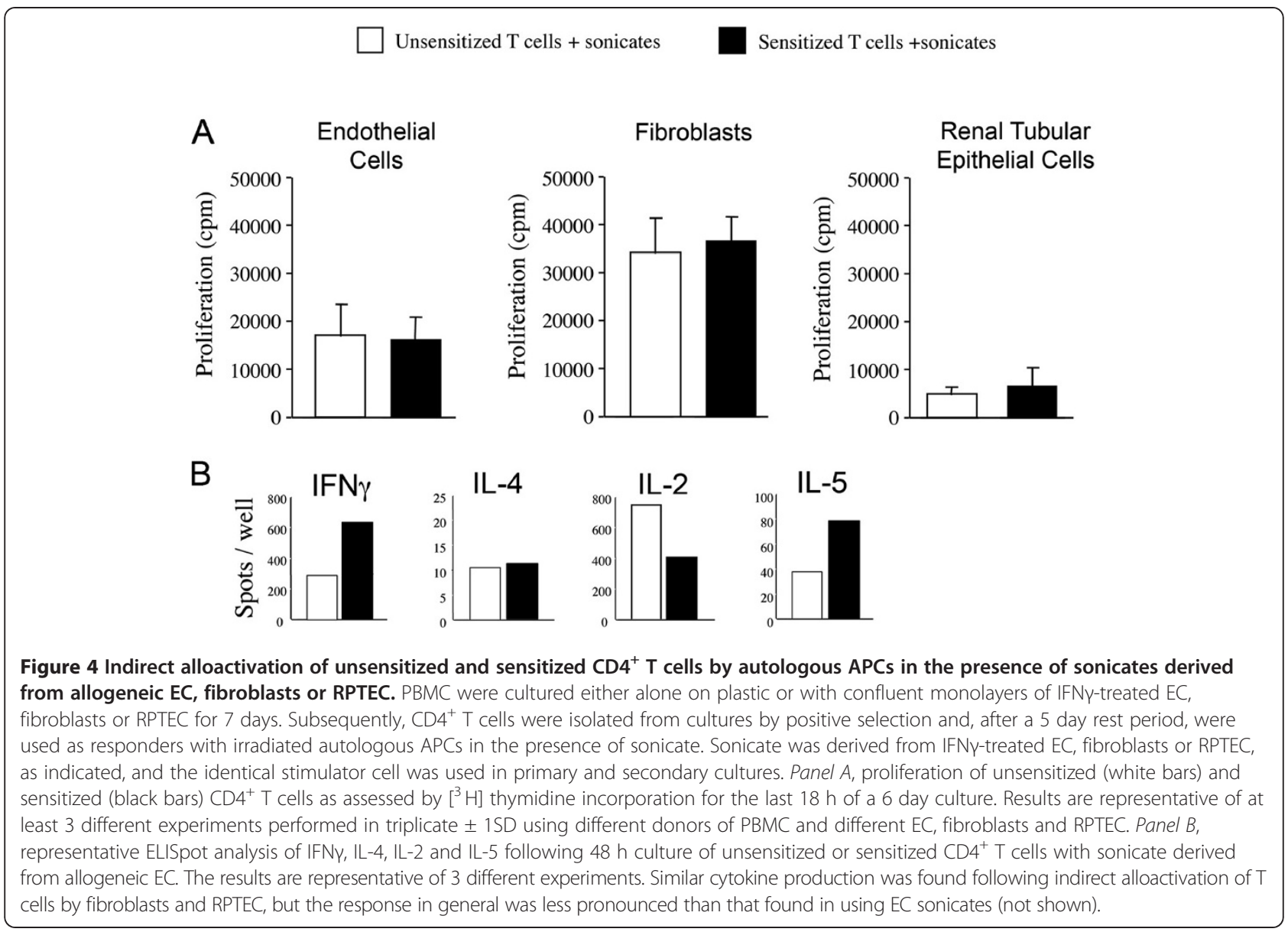

The indirect pathway of allorecognition was initially described based on the observation that passenger leukocyte-depleted renal allografts were rejected at a slower pace than APC replete allografts [43]. It is suggested that recipient APCs traffic through the graft, take up and process soluble MHC alloantigens, as well as dead or necrotic donor cells. After migrating back to lymph nodes these APCs process and present alloantigens as peptides on self $\mathrm{MHC}$ class II molecules to naïve $\mathrm{CD}^{+}{ }^{+} \mathrm{T}$ cells $[9,10]$. Consistent with this model, our in vitro studies indicate that human naive and memory $\mathrm{T}$ cells respond to autologous APCs that have processed membrane particulates from allogeneic cells. In addition, previous studies have confirmed that donor MHC peptides are presented to recipient $\mathrm{T}$ cells through the indirect pathway $[44,45]$, and that these responses occur in patients with chronic allograft rejection [11,16,17]. Indeed, in vivo studies have confirmed that MHC-derived antigens from allografts are commonly processed and can initiate $\mathrm{T}$ effector responses [7,8,10,13,46,47].

During rejection, endothelial cells function to elicit the recruitment of monocyte/APCs as well as activated T cells into the graft $[19,20]$. Multiple studies by our own group, as well as others, have determined that this process and interactions with allogeneic EC may facilitate Th1 [22,48],
Th2 [21,49], or Th17 [50] activation as an integral component of the inflammatory response. Our studies highlighted in this report further confirm these findings, and indicate that this response typically results from ECdependent reactivation of the $\mathrm{CD} 45 \mathrm{RO}^{+}$memory $\mathrm{T}$ cell subset. In contrast, our observations indicate that interstitial cells are ineffective for direct pathway alloactivation of $\mathrm{T}$ cells. These findings are consistent with several other reports [31-34,51] suggesting that fibroblasts and epithelial cells have a limited ability to provide costimulation to $\mathrm{T}$ cells. However, our new findings in this report indicate that once APCs process membrane fragments from interstitial cells, they are most potent to initiate indirect pathway alloactivation. These findings lead to the interpretation that antigens derived interstitial cell types are dominant to induce indirect pathway alloactivation.

An intriguing possibility is that the processing of alloantigen derived from interstitial cell types precedes subsequent emergence of APCs from the graft and their differentiation and maturation into mature APCs/dendritic cells. Indeed, several studies have confirmed that processing is a prerequisite for dentritic cell maturation [52]. Thus, another interpretation of our findings is that the inhibition of the recruitment of monocytes into an allograft or the inhibition 
of alloantigen processing will attenuate the development of naïve $\mathrm{T}$ cell activation/indirect allorecognition.

A limitation of this study is that there is individual variation in precursor frequencies of alloreactive memory $\mathrm{T}$ cells. In the ideal experiment, one might control for precursor cells, and each cell type should be tested against one specific alloantigen that represents a single MHC-derived peptide. Another limitation is that the maturation and differentiation of APCs into mature dendritic cells and their subsequent interaction with naïve and memory $\mathrm{T}$ cells requires specific inflammatory mediators and perhaps the local lymphoid microenvironment. Nevertheless, our findings indicate that endothelial cells are potent to induce alloresponses through both the direct and the indirect pathway. In contrast, fibroblasts and RPTEC selectively activate T cells through the indirect pathway.

\section{Conclusions}

Overall, these in vitro studies clearly demonstrate that different interstitial cell types have potential to activate allogeneic $\mathrm{T}$ cells either through the direct or the indirect pathway of allorecognition. Our studies indicate that memory $\mathrm{T}$ cells are reactivated upon encounter with graft vascular EC, and that interstitial cells are weak or inefficient to elicit direct pathway reactivation of this subset. In contrast, we find that the indirect pathway is potent to induce the alloactivation of both naïve and memory $\mathrm{T}$ cells, and that indirect responses likely occur as a result of APC processing of interstitial cells. Once self-APCs migrate into allografts and have interacted with intragraft cells, their subsequent encounter with $\mathrm{T}$ cells (within an allograft or within a lymph node) has potential to mediate indirect alloactivation.

\section{Competing interests}

The authors declare that they have no competing interests.

\section{Acknowledgements}

The authors wish to thank members of the laboratory especially Drs. Ingrid Vos and Ana-Maria Waaga for their support with technical issues and advice throughout this project.

This work was funded in part by NIH grants R01Al46756 and by a fellowship grant from the American Society of Transplantation to DS.

\section{Author details}

${ }^{1}$ The Transplantation Research Center, Division of Nephrology, Department of Medicine, Children's Hospital Boston, Boston, MA, USA. ²Department of Pediatrics, Harvard Medical School, Boston, MA, USA. 'Division of Nephrology, Children's Hospital Boston, 300 Longwood Ave, Boston, MA 02115, USA.

\section{Authors' contributions}

DS performed the studies, analyzed and interpreted data and drafted the manuscript. CG performed some studies and analyzed data. CW performed some studies and analyzed data. DMB conceived and designed the study, participated in the design of and the interpretation of experiments, analyzed and interpreted data, edited and approved the final draft of the manuscript. All authors read and approved the final manuscript.
Financial conflicts

The authors have no financial conflicts.

Received: 6 February 2012 Accepted: 23 March 2012 Published: 23 April 2012

\section{References}

1. Ingulli E, Alexander SI, Briscoe DM: Transplantation Immunobiology. In Pediatric Nephrology. Volume 6. Edited by Avner ED, Harmon WE, Niaudet P, Yoshikawa N. New York, NY: Springer; 2009: 1835-1866.

2. Nankivell BJ, Alexander SI: Rejection of the kidney allograft. N Engl J Med 2010, 363:1451-1462.

3. Krensky AM, Weiss A, Crabtree G, Davis MM, Parham P: T-lymphocyteantigen interactions in transplant rejection. N Engl J Med 1990, 322:510-517.

4. Pietra BA, Wiseman A, Bolwerk A, Rizeq M, Gill RG: CD4 T cell-mediated cardiac allograft rejection requires donor but not host MHC class II. J Clin Invest 2000, 106:1003-1010

5. Lechler RI, Batchelor JR: Immunogenicity of retransplanted rat kidney allografts. Effect of inducing chimerism in the first recipient and quantitative studies on immunosuppression of the second recipient. Exp Med 1982, 156:1835-1841.

6. Batchelor JR, Kaminski E, Lombardi G, Goldman JM, Lechler RI: Individual variation in alloresponsiveness and the molecular basis of allorecognition. Hum Immunol 1990, 28:96-103.

7. Safinia N, Afzali B, Atalar K, Lombardi G, Lechler Rl: T-cell alloimmunity and chronic allograft dysfunction. Kidney Int 2010, 78:S2-S12.

8. Briscoe DM, Sayegh MH: A rendezvous before rejection: where do T cells meet transplant antigens? Nat Med 2002, 8:220-222.

9. Auchincloss H Jr, Lee R, Shea S, Markowitz JS, Grusby MJ, Glimcher LH: The role of "indirect" recognition in initiating rejection of skin grafts from major histocompatibility complex class II-deficient mice. Proc Natl Acad Sci U S A 1993, 90:3373-3377.

10. Afzali B, Lombardi G, Lechler Rl: Pathways of major histocompatibility complex allorecognition. Curr Opin Organ Transplant 2008, 13:438-444.

11. Baker RJ, Hernandez-Fuentes MP, Brookes PA, Chaudhry AN, Cook HT, Lechler Rl: Loss of direct and maintenance of indirect alloresponses in renal allograft recipients: implications for the pathogenesis of chronic allograft nephropathy. J Immunol 2001, 167:7199-7206.

12. Nadazdin O, Boskovic S, Wee SL, Sogawa H, Koyama I, Colvin RB, Smith RN, Tocco G, O'Connor DH, Karl JA, et al: Contributions of direct and indirect alloresponses to chronic rejection of kidney allografts in nonhuman primates. J Immunology 2011, 187:4589-4597.

13. Golshayan D, Wyss JC, Buckland M, Hernandez-Fuentes M, Lechler Rl: Differential Role of Naive and Memory CD4 + T-Cell Subsets in Primary Alloresponses. A J Transplantation 2010, 10:1749-1759.

14. Chen W, Murphy B, Waaga AM, Willett TA, Russell ME, Khoury SJ, Sayegh $\mathrm{MH}$ : Mechanisms of indirect allorecognition in graft rejection: class II MHC allopeptide-specific T cell clones transfer delayed-type hypersensitivity responses in vivo. Transplantation 1996, 62:705-710.

15. Hornick PI, Mason PD, Baker RJ, Hernandez-Fuentes M, Frasca L, Lombardi G, Taylor K, Weng L, Rose ML, Yacoub MH, et al: Significant frequencies of T cells with indirect anti-donor specificity in heart graft recipients with chronic rejection. Circulation 2000, 101:2405-2410.

16. Salama AD, Najafian N, Clarkson MR, Harmon WE, Sayegh MH: Regulatory CD25+ T cells in human kidney transplant recipients. J Am Soc Nephrol 2003, 14:1643-1651.

17. Najafian N, Salama AD, Fedoseyeva EV, Benichou G, Sayegh MH: Enzymelinked immunosorbent spot assay analysis of peripheral blood lymphocyte reactivity to donor HLA-DR peptides: potential novel assay for prediction of outcomes for renal transplant recipients. J Am SoC Nephrol 2002, 13:252-259.

18. Poggio ED, Clemente M, Riley J, Roddy M, Greenspan NS, Dejelo C, Najafian $\mathrm{N}$, Sayegh MH, Hricik DE, Heeger PS: Alloreactivity in renal transplant recipients with and without chronic allograft nephropathy. J Am SoC Nephrol 2004, 15:1952-1960.

19. Denton MD, Davis SF, Baum MA, Melter M, Reinders ME, Exeni A, Samsonov DV, Fang J, Ganz P, Briscoe DM: The role of the graft endothelium in transplant rejection: evidence that endothelial activation may serve as a clinical marker for the development of chronic rejection. Pediatr Transplant 2000, 4:252-260. 
20. Pober JS, Sessa WC: Evolving functions of endothelial cells in inflammation. Nat Rev Immunol 2007, 7:803-815.

21. Briscoe DM, Alexander SI, Lichtman AH: Interactions between $\mathrm{T}$ lymphocytes and endothelial cells in allograft rejection. Curr Opin Immunol 1998, 10:525-531.

22. Hughes CC, Savage CO, Pober JS: Endothelial cells augment T cell interleukin 2 production by a contact-dependent mechanism involving CD2/LFA-3 interaction. J Exp Med 1990, 171:1453-1467.

23. Denton MD, Geehan CS, Alexander SI, Sayegh MH, Briscoe DM: Endothelial cells modify the costimulatory capacity of transmigrating leukocytes and promote CD28-mediated CD4(+) T cell alloactivation. J Exp Med 1999, 190:555-566.

24. Briscoe DM, Henault LE, Geehan C, Alexander SI, Lichtman AH: Human endothelial cell costimulation of T cell IFN-gamma production. J Immunol 1997, 159:3247-3256.

25. Valujskikh A, Heeger PS: Emerging roles of endothelial cells in transplant rejection. Curr Opin Immunol 2003, 15:493-498.

26. Valujskikh A, Lantz O, Celli S, Matzinger P, Heeger PS: Cross-primed CD8(+) $T$ cells mediate graft rejection via a distinct effector pathway. Nat Immunol 2002, 3:844-851.

27. Pober JS, Orosz CG, Rose ML, Savage CO: Can graft endothelial cells initiate a host anti-graft immune response? Transplantation 1996, 61:343-349.

28. Marelli-Berg FM, Hargreaves RE, Carmichael P, Dorling A, Lombardi G, Lechler RI: Major histocompatibility complex class II-expressing endothelial cells induce allospecific nonresponsiveness in naive T cells. $J$ Exp Med 1996, 183:1603-1612.

29. Orosz CG: Lymphocyte-endothelial interactions and tolerance induction. Clin Transplant 1994, 8:188-194.

30. Kreisel D, Krasinskas AM, Krupnick AS, Gelman AE, Balsara KR, Popma SH, Riha M, Rosengard AM, Turka LA, Rosengard BR: Vascular endothelium does not activate $\mathrm{CD} 4+$ direct allorecognition in graft rejection. $J$ Immunology 2004, 173:3027-3034.

31. Waeckerle-Men Y, Starke A, Wahl PR, Wuthrich RP: Limited costimulatory molecule expression on renal tubular epithelial cells impairs T cell activation. Kidney Blood Press Res 2007, 30:421-429.

32. Corrigall VM, Solau-Gervais E, Panayi GS: Lack of CD80 expression by fibroblast-like synoviocytes leading to anergy in T lymphocytes. Arthritis Rheum 2000, 43:1606-1615.

33. Deshpande M, Tipnis S, Shetty P, Ghosh D, Viswanathan C, Majumdar AS: Immunologic properties of human dermal fibroblasts. Hum Immunol 2010, 71:1089-1098.

34. Rajasekar MR, Proud G, Taylor RM, Kirby JA: T-cell anergy: a consequence of interaction between $T$ cells and allogeneic rat renal epithelial cells. Transpl Int 1994, 7(Suppl 1):S563-566.

35. Gimbrone MA Jr, Cotran RS, Folkman J: Human vascular endothelial cells in culture. Growth and DNA synthesis. J Cell Biol 1974, 60:673-684.

36. Marelli-Berg FM, Frasca L, Weng L, Lombardi G, Lechler Rl: Antigen recognition influences transendothelial migration of CD4+ T cells. $J$ Immunol 1999, 162:696-703.

37. Paddock SW: Incident light microscopy of normal and transformed cultured fibroblasts stained with coomassie blue R250. J Microsc 1982 128:203-205.

38. Smyth LA, Herrera OB, Golshayan D, Lombardi G, Lechler RI: A novel pathway of antigen presentation by dendritic and endothelial cells: Implications for allorecognition and infectious diseases. Transplantation 2006, 82:S15-18.

39. Mustafa M, Bakhiet M, Wondimu B, Modeer T: Effect of triclosan on interferon-gamma production and major histocompatibility complex class II expression in human gingival fibroblasts. J Clin Periodontol 2000, 27:733-737.

40. Yard BA, Lorentz CP, Herr D, van der Woude FJ: Sulfation-dependent down-regulation of interferon-gamma-induced major histocompatibility complex class I and II and intercellular adhesion molecule-1 expression on tubular and endothelial cells by glycosaminoglycans. Transplantation 1998, 66:1244-1250.

41. Guinan EC, Smith BR, Doukas JT, Miller RA, Pober JS: Vascular endothelial cells enhance $T$ cell responses by markedly augmenting IL-2 concentrations. Cell Immunol 1989, 118:166-177.

42. Karmann K, Hughes CC, Fanslow WC, Pober JS: Endothelial cells augment the expression of CD40 ligand on newly activated human CD4+ T cells through a CD2/LFA-3 signaling pathway. Eur J Immunol 1996, 26:610-617.
43. Lechler RI, Batchelor JR: Restoration of immunogenicity to passenger celldepleted kidney allografts by the addition of donor strain dendritic cells. J Exp Med 1982, 155:31-41.

44. Frasca L, Amendola A, Hornick P, Brookes P, Aichinger G, Marelli-Berg F, Lechler Rl, Lombardi G: Role of donor and recipient antigen-presenting cells in priming and maintaining $T$ cells with indirect allospecificity. Transplantation 1998, 66:1238-1243.

45. Lechler R, Lombardi G: Structural aspects of allorecognition. Curr Opin Immunol 1991, 3:715-721.

46. Sayegh $\mathrm{MH}$ : Why do we reject a graft? Role of indirect allorecognition in graft rejection. Kidney Int 1999, 56:1967-1979.

47. Sayegh $\mathrm{MH}$, Carpenter CB: Role of indirect allorecognition in allograft rejection. Int Rev Immunol 1996, 13:221-229.

48. Shiao SL, Kirkiles-Smith NC, Shepherd BR, MCNiff JM, Carr EJ, Pober JS: Human effector memory CD4+ T cells directly recognize allogeneic endothelial cells in vitro and in vivo. J Immunol 2007, 179:4397-4404.

49. Ma W, Pober JS: Human endothelial cells effectively costimulate cytokine production by, but not differentiation of, naive CD4+ T cells. J Immunol 1998, 161:2158-2167.

50. Taflin C, Favier B, Baudhuin J, Savenay A, Hemon P, Bensussan A, Charron D, Glotz D, Mooney N: Human endothelial cells generate Th17 and regulatory T cells under inflammatory conditions. Proc Natl Acad Sci U S A 2011, 108:2891-2896.

51. Ohyama H, Nishimura F, Meguro M, Takashiba S, Murayama Y, Matsushita S: Counter-antigen presentation: fibroblasts produce cytokines by signalling through HLA class II molecules without inducing T-cell proliferation. Cytokine 2002, 17:175-181.

52. Randolph GJ, Beaulieu S, Lebecque S, Steinman RM, Muller WA: Differentiation of monocytes into dendritic cells in a model of transendothelial trafficking. Science 1998, 282:480-483.

doi:10.1186/2047-1440-1-4

Cite this article as: Samsonov et al: Differential activation of human T cells to allogeneic endothelial cells, epithelial cells and fibroblasts in vitro. Transplantation Research 2012 1:4

\section{Submit your next manuscript to BioMed Central and take full advantage of:}

- Convenient online submission

- Thorough peer review

- No space constraints or color figure charges

- Immediate publication on acceptance

- Inclusion in PubMed, CAS, Scopus and Google Scholar

- Research which is freely available for redistribution 